\title{
Determination of Physical and Mechanical Properties of Potatoes and the Importance in Food Chemistry
}

\section{LTAIEF LAMMARI*, SANA BEN KHLIFA, LINDA HAMED, KHALIL HAMRAOUI, HASSEN KHARROUBI}

Laboratory of Mechanical and Agro-industrial Engineering, National School of Engineers of Medjez El Bab Road of Kef Km 5, University of Jendouba, Tunisia

Abstracts: The physical, mechanical and morphological data of foods are essential in the separation and aeration processes, whether in the case of transportation or storage, in order to preserve the freshness of these products, and in this context we try to predict and implement some experiments that will be validated through equations, where it is desirable to determine the relationships among the characteristics. Key physical and mechanical parameters, for example, fruits are often classified by size, but it may be more economical to develop a method that classifies them by weight when designing a machine, the relationship between weight and intermediate dimensions is essential. These physical and technical properties of the potato had to be evaluated to know the effect of surface conditioning, the limits of loading without damage, as well as to allow the volume of breathing during all stages of the life cycle especially in the case of harvesting, transportation and storage, which is also important for the design of harvesting and harvesting equipment. Psychiatric treatment. The shape of potato tubers is as complex as any agricultural product, therefore, in order to determine the mechanical and physical properties, it has become more and more necessary to find all the necessary data and prove the basic viscoelastic behavior of this material, especially since then. The product is consumed by all worlds.

Keywords: potato, experimental tests, physical properties, mechanical properties, viscoelastic

\section{Introduction}

All countries face a range of structural security and nutrition challenges due to population growth rates, tight and increasingly depleted natural agricultural stocks and the impacts of climate change, for this, the importance of these agricultural products becomes the guarantee of the health and economic value for each country $[1,2]$. Therefore, since potatoes are classified after wheat and rice as a strategic product. Therefore, it becomes clear to research the physical and mechanical properties of this product and know the different parameters assuming that there are many varieties of potatoes $[3,4]$. Choosing the right variety is the first step in planting, yield and productivity in general, and the appropriate variety must be chosen for the conditions of the area to be cultivated, in addition to making this variety marketable, the most important of which is the possibility of obtaining potato crops, [5, 6]. Knowing that potatoes have colour and elasticity, they certainly have appropriate thermal-physical behavior [7, $8]$, and the geometry of this product is complex and it is very important to find an algebraic and experimental link between the different evaluation criteria and this is what we try to do must be done, especially since potatoes can be prepared in dishes of different shapes and have Also, multiple transformations in industry, in this case, it is important to determine all of the coefficients [9].

\section{Materials and methods}

\subsection{Materials}

Two types of potato tubers were selected for this study (spunta and daifla) as show (Figure 1) for the available experiments which were harvested and not stored. The test is performed at $25^{\circ} \mathrm{C}$ and a digital caliper is used for the measurement. Lengths, widths and thicknesses. The mass of the samples was determined with an electronic balance with a sensitivity of $0.01 \mathrm{~g}$.

*email: ltaieflammari@gmail.com 


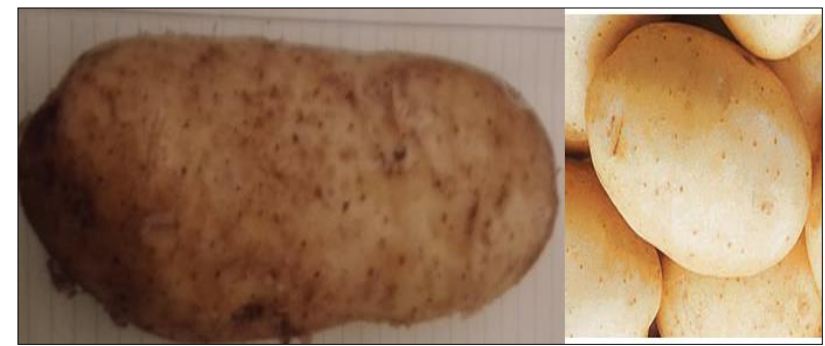

Figure 1. The morphology of the two varieties studied (spunta, daifla)

To determine the mechanical behavior of potatoes, tensile and compression tests should be performed on a digital tensile machine (Figure 2).

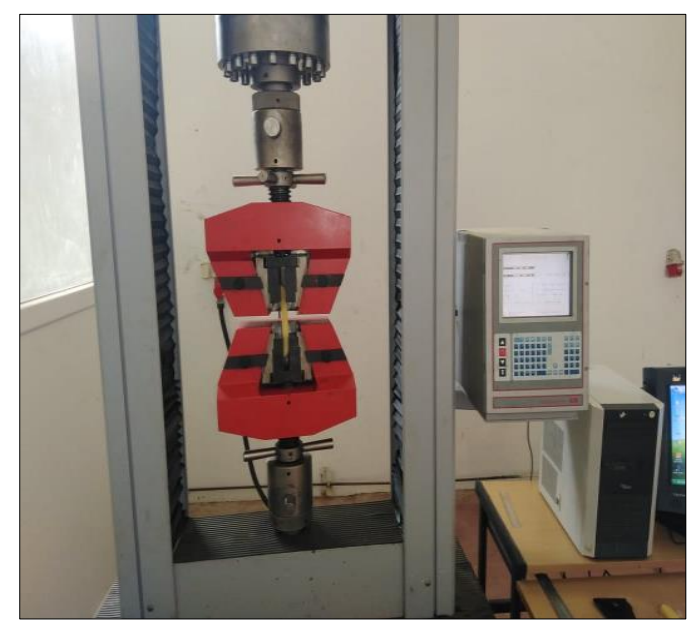

Figure 2. Tensile test of a potato sample on a digital machine

\subsection{Preparation of the sample}

\subsubsection{Tensile case}

Tensile tests give a deformation which can be used to determine the modulus of elasticity, and these tests are difficult to perform, mainly because of the problem of surface tearing which can disturb the results but also because good sample preparation requires considerations [10,11], we therefore proposed A model with modifications compared to the known models, we try to minimize as much as possible the geometric limits of the test specimen but also to lose the known refernce [12,13] (Figure 3).

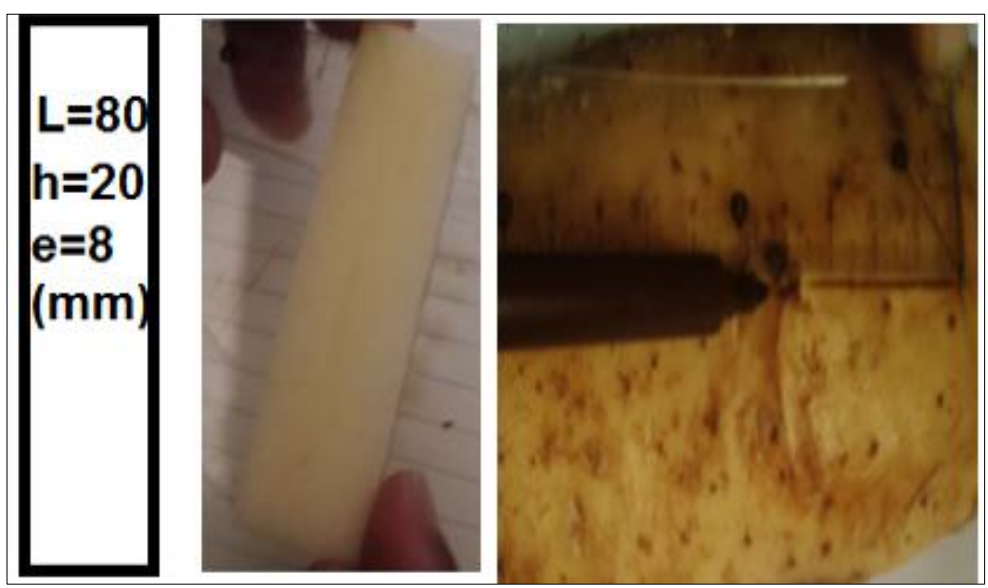

Figure 3. Preparation of the test sample 
An experimental procedure has been set up to measure and calculate some of these arameters. The experimental studies were carried out in a test laboratory on a digital traction machine (Figure 2).

\subsubsection{Compression case}

For the compression test, cylindrical test pieces were used (dimensions of the test pieces: 20 x 25 $\mathrm{mm}$ ) of potato tubers (Figure 4) [14].

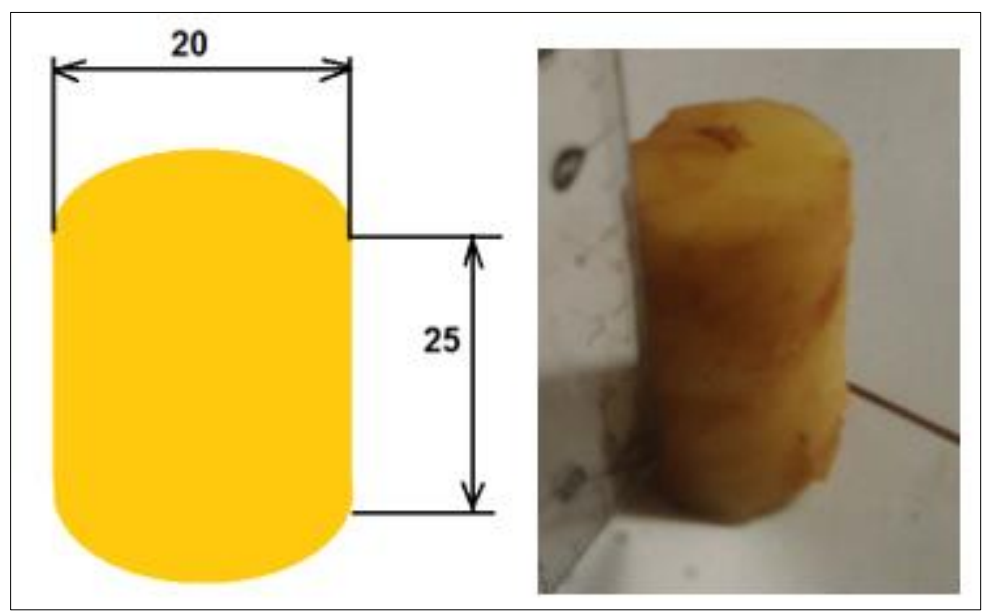

Figure 4. Sample compression test

The mechanical properties of foods are most often determined by compression testing, primarily due to the ease of sample preparation and the simplicity of test performance $[10,12]$. As a result, there have been a considerable number of studies on the compressive strength of potatoes [15-18].

\subsection{Physical properties}

To determine the average size of this product, three linear dimensions, namely length $(\mathrm{L}, \mathrm{mm})$, width $(\mathrm{W}, \mathrm{mm})$ and thickness $(\mathrm{T}, \mathrm{mm})$ were measured (Figure 2) The average diameter geometric (Dg, equation 1) and the arithmetic mean diameter (Da, equation 2) were calculated [19-21].

$$
D g=\sqrt[3]{L W T}
$$

and

$$
D a=\frac{L+W+T}{3}
$$

In the hypothesis, all these dimensions were measured in a medium at room temperature $\left(25^{\circ} \mathrm{C}\right)$ that is to say that the increase in the moisture content of the tuber has no significant effect on its linear dimensions.

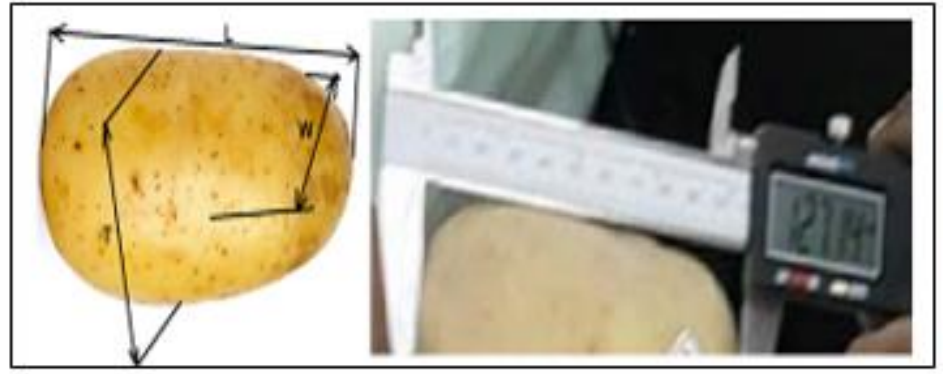

Figure 5. Positioning of the three axes of potato measurements 
The sphericity $(\varnothing)$, which is defined as the ratio of the area of the sphere, has the same volume as that of the fruit to the area, was determined by equation 3 [22]:

$$
\emptyset=\frac{D_{g}}{L}
$$

The specific surface $(S)$ of the potato was evaluated by the equation 4 [22]:

$$
S=\pi\left(D g^{2}\right)
$$

Bulk density and actual density are useful in determining fruit ripeness, texture, and sweetness [23]. Bulk density was determined using the mass / volume relationship [24, 25], including pores and water (apparent volume). The terms bulk density and bulk size are used for granular materials.

$$
\rho a p=\frac{m_{s}+m_{w}}{v_{s}+v_{w}+v_{p}}
$$

The real density is prescribed by dividing the weight of the samples by the volume obtained from the water displacement method, disregarding the pores of the material (real volume). In the case of granular materials, the terms density and volume of particles are used [26].

$$
\text { pre }=\frac{m_{s}+m_{w}}{v_{s}+v_{w}}
$$

The mass of each part was determined using an electronic balance with a sensitivity of $0.01 \mathrm{~g}$ (Figure 6). Fruit size was measured by the water displacement method. The fruits were lowered into a graduated beaker containing water and the mass of water displaced by the fruits was recorded. Finally, the fruit densities It was calculated using the following equation (7).

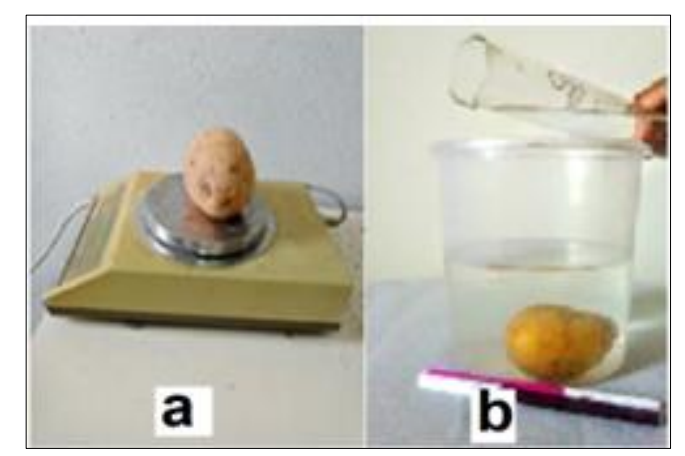

Figure 6. Determination of the true density of potato

$$
\rho a=\frac{V t}{M r e c} \quad \text { et } \quad \rho r=\frac{V}{M}
$$

The porosity (P) of a bulk sample was calculated from the actual density and bulk density values using the relationship given by Mohsenin (1986) [9] as follows:

$$
P=\left(1-\frac{\rho r}{\rho A}\right) \times 100
$$

The bulk density presented an important effect in agricultural field, in case of separating products and sorting them according to mass and quality, the potatoes was studied with standard estimated shapes 
such as a volume of an ellipsoid (Ve) (Daifla), a volume of a flattened spheroid (Vsp) (case of spunta) $[9,27,28]$, the case of our test (equation 9):

$$
V e=\frac{\pi}{6} \times L \text { And } V s p=\frac{\pi}{6} L W T
$$

\subsection{Mechanical property}

Based on Hooke's theory, a cylindrical or cubic sample of the tissue of the product is prepared, stretched or compressed uniaxially between two jaws to a certain degree of deformation with a fairly low velocity (casi-static) as shown in the condition of linearity, called Hooke's law the law is formulated in equation (10):

$$
E=\frac{\sigma}{\varepsilon}=\frac{\frac{F}{S}}{\frac{\Delta L}{L}}=\frac{F \cdot L}{S . \Delta L}
$$

The mechanical properties of the potato, such as elasticity, tensile modulus, and other indicators, can be used to predict the extent of damage. To be an important indicator of elastic stress, from the stressstrain curve, the maximum slope value can be obtained [29].

\begin{tabular}{|c|c|c|}
\hline Test Type & Materials tested & Reference \\
\hline Compression Test & $\begin{array}{l}\text { Apple, Potato, Corn, Peach, Tomato, } \\
\text { Soybean and Wheat }\end{array}$ & $\begin{array}{l}\text { Arnold Et Mohsenin (1971), Shelef Et } \\
\text { Mohsenin (1969), Fridley Et Coll } \\
\text { (1968), Jindal Et Techasena (1985), } \\
\text { Misra Et Young (1981), Arnold Et } \\
\text { Roberts (1969) }\end{array}$ \\
\hline Tensile test & Cherry And Tomato, potato & \multirow{2}{*}{$\begin{array}{c}\text { Levin Et Coll. (1959), } \\
\text { Huff (1967) Balastreire Et } \\
\text { Coll. (1982), Khzaie (2002) }\end{array}$} \\
\hline Bending Test & Corn And Peas & \\
\hline
\end{tabular}

Table 1. Usual tests used to determine the elasticity modulus [30]

One can necessarily choose the models followed according to their geometry, dimensions and size of the targeted product, that is to say of what type of tests are the traction, the compression or the bending, with reliability restrictions on the machines used.

Apparent elastic properties, such as Poisson's ratio, can be used to understand the loading response behavior of food materials. Due to the difficulty of measuring the Poisson's ratio of fruits and vegetables, (due to the water which varies depending on the product or time) for this it can be calculated as follows $[31,32]$,

$$
\mu=\frac{0,5 \mathrm{Mw}+0.1(100-\mathrm{Mw})}{100}
$$

with Mw average water content of fruits and vegetables

The method is as follows, for this we take a cylinder similar to the sample of the compression test, we weigh it then we keep it in the air and each time we weigh it again to determine the amount of water until 'to become at constant weight (Figure 4) .

\section{Results and discussions}

The potatoes studied undergo many simple operations such as cleaning, and attempts have been made to maintain a temperature capable of protecting them. In summary, the physical properties of 
potato tubers (Spunta, Daifla) were calculated numerically, mean length, width and thickness, geometric and arithmetic mean of diameter, sphericity, aspect ratio, mass and volume, from of measurements made on one hundred and one sample of each variety, at room temperature of $25^{\circ} \mathrm{C}$, as suggested in Table 2 .

Table 2. Physical characteristics of the potato tuber (100 samples of each type)

\begin{tabular}{|c|c|c|c|}
\hline Variety & Variety & Minimum deviation & Maximum deviation \\
\hline & Spunta: S Daifla: D & & \\
\hline \multirow[t]{2}{*}{ M en $g$} & $\mathrm{~S}$ & 54.23 & 801,21 \\
\hline & $\mathrm{D}$ & 79.86 & 712,3 \\
\hline \multirow[t]{2}{*}{$\mathrm{L}(\mathrm{mm})$} & $S$ & 59.39 & 252,89 \\
\hline & $\mathrm{D}$ & 54.9 & 178,2 \\
\hline \multirow[t]{2}{*}{$\mathrm{W}(\mathrm{mm})$} & $S$ & 42.89 & 89.12 \\
\hline & $\mathrm{D}$ & 52.3 & 87.32 \\
\hline \multirow[t]{2}{*}{$\mathrm{T}(\mathrm{mm})$} & $S$ & 39.21 & 60.12 \\
\hline & $\mathrm{D}$ & 49.9 & 72.32 \\
\hline \multirow[t]{2}{*}{$\mathrm{Dg}(\mathrm{mm})$} & $S$ & 33292,3889 & 451652,638 \\
\hline & $\mathrm{D}$ & 47758,791 & 375109,955 \\
\hline \multirow[t]{2}{*}{$\mathrm{Da}(\mathrm{mm})$} & $\mathrm{S}$ & 47,16333333 & 134,043333 \\
\hline & $\mathrm{D}$ & 52,36666667 & 1013,52 \\
\hline \multirow[t]{2}{*}{$\mathrm{p}$} & $\mathrm{S}$ & 22,99110082 & 29,2878974 \\
\hline & $\mathrm{D}$ & 34,50441477 & 33,5587461 \\
\hline \multirow[t]{2}{*}{$\mathrm{S}\left(\mathrm{mm}^{2}\right)$} & $S$ & 104538,1011 & 1418189,28 \\
\hline & $\mathrm{D}$ & 149962,6037 & 1177845,26 \\
\hline \multirow[t]{2}{*}{$\varnothing$} & $\mathrm{S}$ & 560,5723 & 1785,9648 \\
\hline & $\mathrm{D}$ & 869,9233333 & 2104,99413 \\
\hline \multirow[t]{2}{*}{$\mathrm{V}\left(\mathrm{mm}^{3}\right)$} & $S$ & 50078,3 & 695600,5 \\
\hline & $\mathrm{D}$ & 72366,98 & 691223,5 \\
\hline $\mathrm{Vsp}\left(\mathrm{mm}^{3}\right)$ & $S$ & 52269,05057 & 709094,642 \\
\hline $\operatorname{Ve}\left(\mathrm{mm}^{3}\right)$ & $\mathrm{D}$ & 78587,61699 & 711071,957 \\
\hline \multirow{2}{*}{$\begin{array}{c}\text { Density calculate } \\
\left(\mathrm{Kgm}^{-3}\right)\end{array}$} & $\mathrm{S}$ & 1037,516454 & 1129,90559 \\
\hline & $\mathrm{D}$ & 1016,19063 & 1001,72703 \\
\hline $\begin{array}{c}\text { apparent density } \\
\left(\mathrm{Kgm}^{-3}\right)\end{array}$ & $=$ & $\mathrm{D}=665,56$ & $\mathrm{Sp}=798,98$ \\
\hline $\begin{array}{l}\text { density measure } \\
\text { (true), }\left(\mathrm{Kgm}^{-3}\right)\end{array}$ & & $\mathrm{D}=1018,25$ & $\mathrm{Sp}=997,89$ \\
\hline
\end{tabular}

*As shown in Table 1, the mean bulk density values between (Daifla $665.56 \mathrm{kgm}^{-3}$, Spounta of $798.98 \mathrm{kgm}^{-3}$ ), the actual density were respectively (Daifla $101818 \mathrm{k} \cdot \mathrm{gm}^{-3}$, spunta $997.89 \mathrm{k}_{\mathrm{gm}} \mathrm{gm}^{-3}$ ) and the density is calculated respectively (daifla between $1016.19 \mathrm{k.gm}{ }^{-3}$ and $1001.72{\mathrm{k} . \mathrm{gm}^{-3}}^{-3}$, spunta from $1037.52{\mathrm{k} . \mathrm{gm}^{-3}}^{-3}$ to $1129.90 \mathrm{k} \cdot \mathrm{gm}^{-3}$ ). This variation is explained by the difference in geometry of the two varieties to be studied, as well as the types of varieties studied. 
*after preparing the necessary test conditions, the machine is started until it breaks again, recording the measurements to extract the curves where there are three zones of linear elastic zone, a second nonlinear zone which explains why this viscoelastic material, and to justify this main property we load a specimen of spunta then we unload it to then resume the drawing condition again, we can clearly see this viscoelasticity of the potato (Figure 10) [22, 33-35]. A third or material will also be completely damaged and these results will appear after stress testing (each test has five repeat tests). He indicated that the advantage of the tensile test is that the onset of fracture can be easily observed as it is often outside the sample, so it can be seen that sample preparation times can also be guided towards errors as well as on the choice of machines. We observe the modulus of elasticity of spunta and slightly lower than the modulus of daifla, this can be explained by the tensioned geometry:

$$
(\text { Espunta }=3 \sim 3.4 M p a, \text { Edaifla }=3.9 \sim 4.2 \text { Mpa with } \mu=0.46 \sim 0.485)
$$

and by comparison we find that the results found are acceptable $[17,36]$.

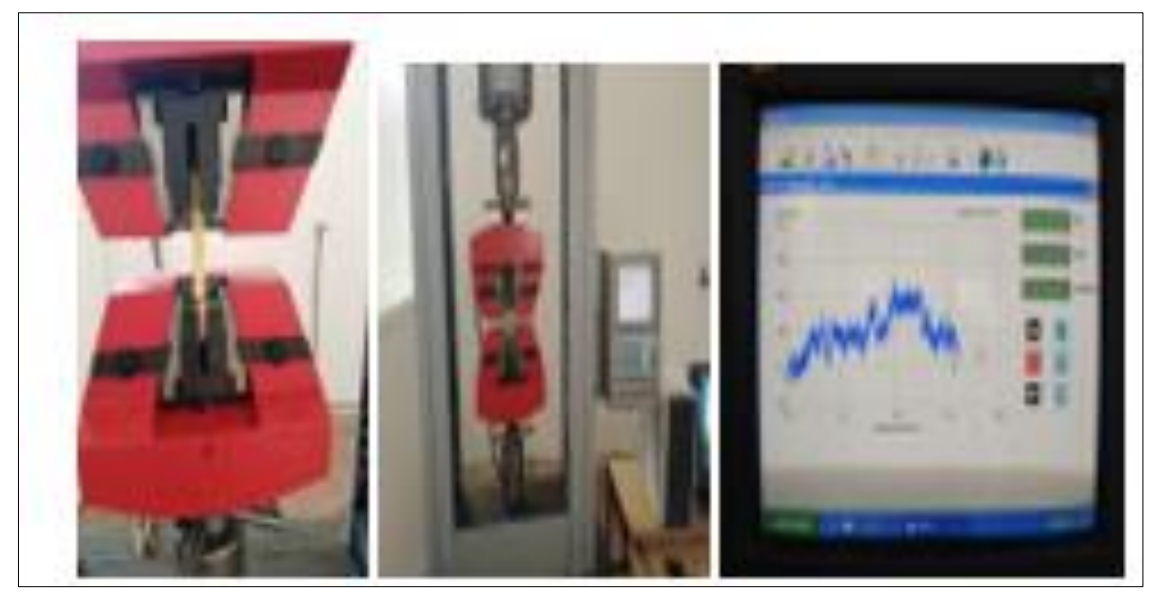

Figure 7. Fixation of the specimen

and course of the tensile test

The following Figures 8-9 illustrate the stress-strain relationship for the two varieties to be studied respectively daifla / spunta, as well as the response of the potato in the event of loading and unloading.

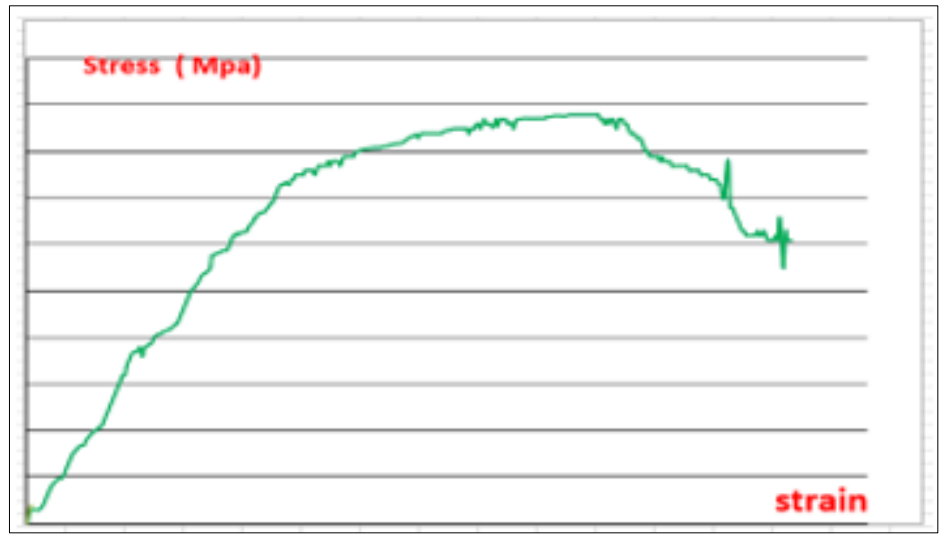

Figure 8. Stress curve - strain obtained from the daifla texture (tensile test) 


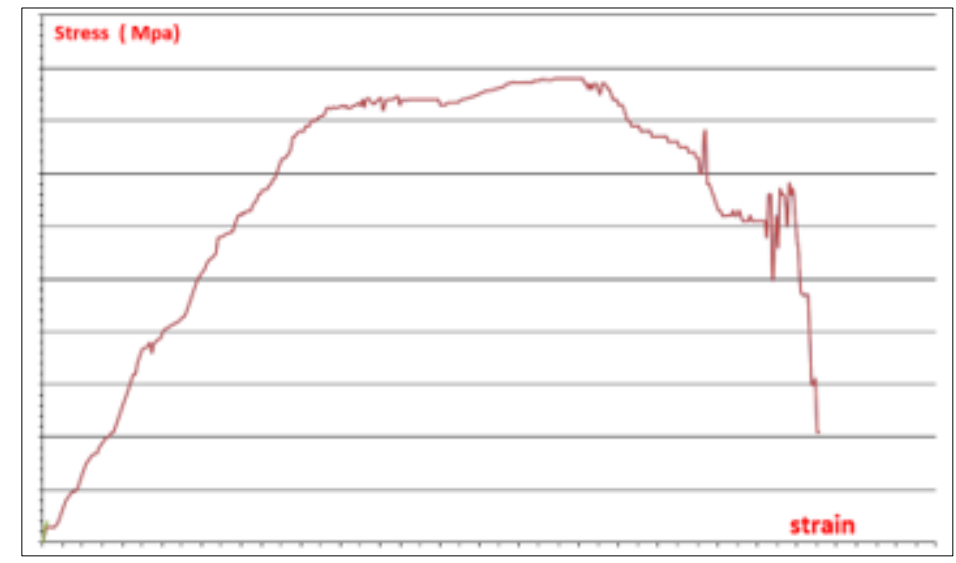

Figure 9. Stress curve - strain obtained from the spunta texture (tensile test)

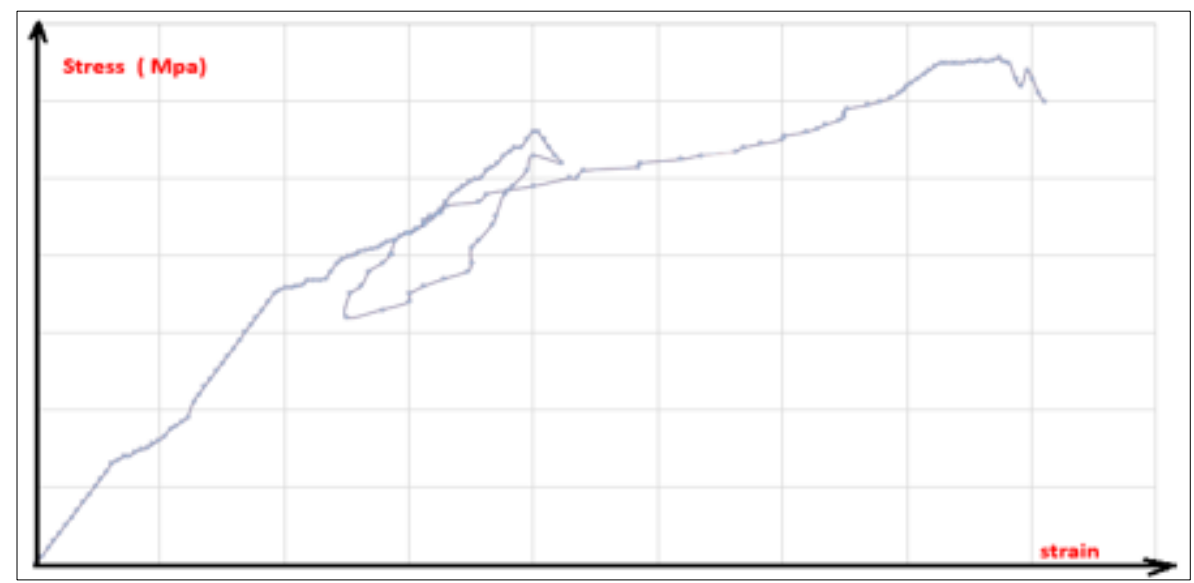

Figure 10. Cyclic potato loading and unloading tests (spunta)

Hysteresis loop during cyclic sample loading and unloading shows energy loss due to phase shift between stresses during unloading. This observed behavior confirms the viscoelastic nature of the potato (Figure 10).

In general, stress relaxation depends on the stress test [13] in this case the loading speed of the potato specimen low $(2.5 \mathrm{~mm} / \mathrm{min})$. The downside of the compression test, however, is that the friction between the sample and the loading plates results in an inhomogeneous stress-strain state in the addition [37] (Figure 11).
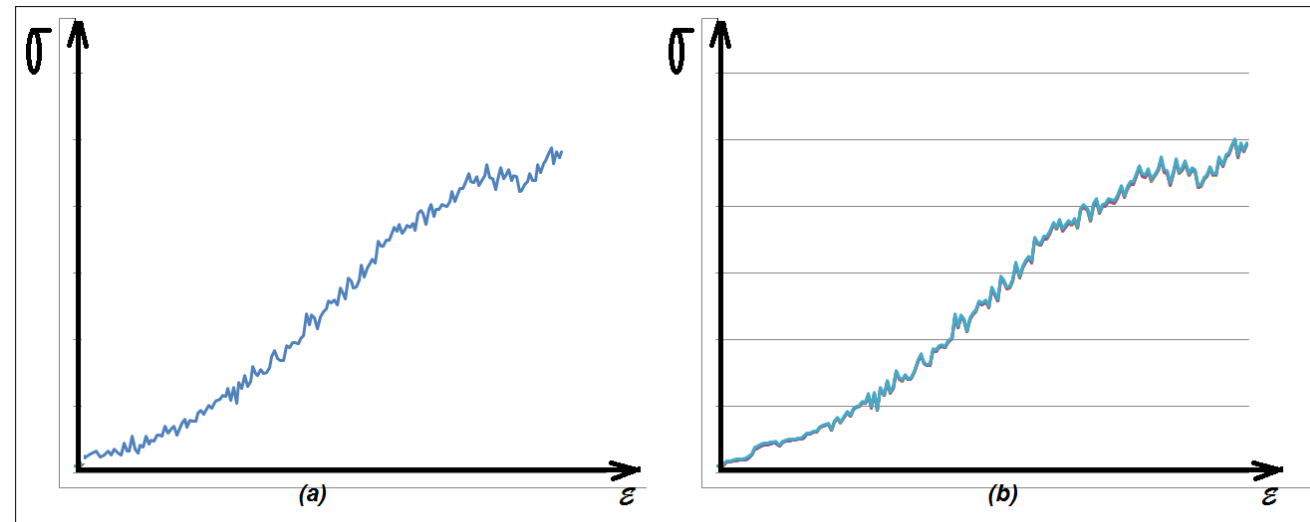

Figure 11. Stress - strain curve obtained from the texture daifla (a) spunta (b) 
The elasticity moduli of the two varieties framed between 4 and $4.5 \mathrm{Mpa}$, one can also draw that there are many slips under the effect of loadings and also note that one not succeeded in making the tests of cahrgement and unfragment of the test

\section{Conclusions}

After this study, it was found that the physical and mechanical properties of the two varieties of potatoes have non-identical geometric shapes, which were objectively verified, we determined the mechanical physical parameters, modulus of elasticity, Poisson's ratio and it is also very important, as it was found that this value is not constant due to the storage conditions of this agricultural product and is proportional to the rate of water evaporation like any other parameter in this study in as density and all the results found are a support for the design of the equipment Intervention and a good conservation as well as the improvement of the desired energy for the diversion of the target. We can also say that the variation of the parameters is due to the geometry of the shapes and due to the physical and chemical composition, it is verified that it is a viscous elastic material.

\section{References}

1.EL-BELTAGY, A., MADKOUR, M., (2012). Impact of Climate Change on Arid Lands Agriculture. Agriculture and Food Security, 1(1), 1-12.

2.SHAHZAD, A., ULlAH, S., DAR, A. A., SARDAR, M. F., MEHMOOD, T., TUFAIL, M. A., HARIS, M., (2021). Nexus on Climate Change: Agriculture and Possible Solution to Cope Future Climate Change Stresses. Environmental Science and Pollution Research, 1-22.

3.CAREY, E. E., HAGENIMANA, V., K'OSAMBO, L., OYUNGA, M. A., BENESI, I., SMIT, N., LOW, J., (1998). Using Orange-Fleshed Sweetpotato Varieties to Combat Vitamin A Deficiency and Enhance Market Opportunities for Smallholder Farmers in Sub-Saharan Africa. Food Security and Crop Diversification in Sadc Countries: The Role of Cassava and Sweetpotato, 17-19

4.DEVAUX, A., KROMANN, P., ORTIZ, O., (2014). Potatoes for Sustainable Global Food Security. Potato Research, 57(3-4), 185-199

5. BONIERBALE, M. W., AMOROS, W. R., SALAS, E., DE JONG, W., (2020). Potato Breeding. The Potato Crop, 163

6. BURGOS, G., SOSA, P., CHACALTANA, C., MUÑOA, L., SCURRAH, M., SALAS, E., ZUM FELDE, T., (2021). Iron Concentration of Potato and Sweetpotato Clones as Affected by Location. Journal of Agriculture and Food Research, 3, 100100.

7. LAMMARI, LTAIEF, SANA BEN KHLIFA HASSEN KHARROUBI, "Experimental Study of Heat Propagation Characteristics in Potatos." Sylwan 164.6 (2020).

8. ZHANG, Y., YANG, H., ZHENG, H., YUAN, D., MAO, L., (2021). Physical Properties and Salt Release of Potato Starch-Based Emulsion Gels with Osa Starch-Stabilized Oil Droplets. Lwt, 141, 110929.

9.AHANGARNEZHAD, N., NAJAFI, G., JAHANBAKHSHI, A., (2019). Determination of The Physical and Mechanical Properties of a Potato (The Agria Variety) In Order to Mechanise The Harvesting and Post-Harvesting Operations. Research in Agricultural Engineering, 65(2), 33-39.

10.LUYTEN, H., VAN VLIET, T., WALSTRA, P., (1992). Comparison of Various Methods to Evaluate Fracture Phenomena in Food Materials. Journal of Texture Studies, 23(3), 245- 266.

11. CHEN P, WHITNEY L, PELEG M., (1994) Some Tensile Characteristics of Bread Crumb. Journal of Texture Studies 25, 299-310

12. BOURNE MC, (1982) Principles of Objective Texture Measurement. In: Stewart Gf, Schweigert Bs, Hawthorn J (Eds) Food Texture and Viscosity: Concept and Measurement, Academic Press, New York, Pp 45-117

13. CANET W, ALVAREZ MD, GIL MJ, (2007) The Effect of Test Conditions on Failure Parameters During Uniaxial Compression of Potato Tissue. International Jour- Nal Of Food Science and Technology $42,728-738$ 
14. CAGLAYAN, N., ORAL, O., CELIK, H. K., CINAR, R., RODRIGUES, L. C. D. A., RENNIE, A. E., AKINCI, I., (2018). Determination of Time Dependent Stress Distribution on A Potato Tuber During Drop Case. Journal of Food Process Engineering, 41(7), E12869

15. CHU, C. F., PELEG, M., (1985). The Compressive Behavior of Solid Food Specimens with Small Height to Diameter Ratios 2. Journal of Texture Studies, 16(4), 451-464.

16. SCANLON, M. G., LONG, A. E., (1995). Fracture Strengths of Potato Tissue Under Compression and Tension at Two Rates of Loading. Food Research International, 28(4), 397-402.

17. ÁLVAREZ, M. D., CANET, W., (1997). Effect of Pre-Cooling and Freezing Rate on Mechanical Strength of Potato Tissues ( $\mathrm{Cv}$ Monalisa) At Freezing Temperatures. Zeitschrift Für Lebensmitteluntersuchung Und-Forschung A, 205(4), 282-289.

18. CANET, W., FERNÁNDEZ, C., ALVAREZ, M. D., (2009). Some Objective Instrumental Methods for Evaluating the Texture of Solid Potato Tissue (Solanum Tuberosum L.). Potato Iii. Food 3 (Special Issue 1), 1-12.

19. ARFA, G. K., (2007). The Effect of Harvesting Operation on Potato Crop Handling. Misr J. Agric. Eng, 24(3), 492-503.

20. ELBATAWI, I. E., EBAID, M. T., HEMEDA, B. E., (2008). Determination of Potato Water Content Using Nir Diffuse Reflection Method. Misr J. Ag. Eng, 25(4), 1279-1292.

21. ABD ELHAY, Y. B., (2017). Determination of Some Physical and Mechanical Properties of Potato Tubers Related to Design of Sorting, Cleaning and Grading Machine. Misr Journal of Agricultural Engineering, 34(3), 1375-1388.

22. UNAL, H., IZLI, G., IZLI, N., ASIK, B. B., (2017). Comparison of Some Physical and Chemical Characteristics of Buckwheat (Fagopyrum Esculentum Moench) Grains. Cyta-Journal of Food, 15(2), 257-265.

23. KHOSHNAM, F., TABATABAEEFAR, A., VARNAMKHASTI, M. G., BORGHEI, A., (2007). Mass Modeling of Pomegranate (Punica Granatum L.) Fruit with Some Physical Characteristics. Scientia Horticulturae, 114(1), 21-26.

24.FRASER, B. M., VERMA, S. S., MUIR, W. E., (1978). Some Physical Properties of Fababeans. Journal of Agricultural Engineering Research, 23(1), 53-57.

25. JAHROMI, M. K., RAFIEE, S., JAFARI, A., BOUSEJIN, M. G., MIRASHEH, R., MOHTASEBI, S.S., (2008). Some Physical Properties of Date Fruit (Cv. Dairi). International Agrophysics, 22(3), 221224.

26.ARANA, I. (Ed.), (2012). Physical Properties of Foods: Novel Measurement Techniques and Applications. Crc Press.

27. TABATABAEEFAR, A., (2002). Size nd Shape of Potato Tubers. International Agrophysics, 16(4), 301-305.

28.FOnMBOH, D. J., ACHICK, T. E., NTUNGWEN, F. C., DIVINE, B. N., (2019). Physical Characterization of Two Wild Varieties of Edible Orchid Tubers. Advances in Bioscience and Bioengineering, 7(4), 72.

29. HETZRONI, A., VANA, A., MIZRACH, A., (2011). Biomechanical Characteristics of Tomato Fruit Peels. Postharvest Biology and Technology, 59(1), 80-84.

30.KHODABAKHSHIAN, R., EMADI, B., (2011). Determination of The Modulus of Elasticity in Agricultural Seeds on The Basis of Elasticity Theory. Middle-East Journal of Scientific Research, 7(3), 367-373

31.KOJIMA T., (1983) Mechanical Properties and Resonant Vibration Characteristics of Fruits, Bulletin of Faculty of Agriculture, Saga University.

32.SIRISOMBOON, P., TANAKA, M., KOJIMA, T., (2012). Evaluation of Tomato Textural Mechanical Properties. Journal of Food Engineering, 111(4), 618-624.

33.SINHA, A., BHARGAV, A., (2020). Young's Modulus Estimation in Food Samples: Effect of Experimental Parameters. Mechanics \& Industry, 21(4), 404 
34.SINGH, D. K., GOSWAMI, T. K., CHOURASIA, M. K., (2006). Physical Properties of Two Popular Indian Potato Varieties. Journal of Food Process Engineering, 29(4), 337-348.

35.GHABEL, R., RAJABIPOUR, A., GHASEMI-VARNAMKHASTI, M., OVEISI, M., (2010). Modeling the Mass of Iranian Export Onion (Allium Cepa L.) Varieties Using Some Physical Characteristics. Research in Agricultural Engineering, 56(1), 33-40.

36.CHEN P, WHITNEY L, PELEG M., (1994) Some Tensile Characteristics of Bread Crumb. Journal of Texture Studies 25, 299-310

37.CHARALAMBIDES M.N., GOH, S.M., LIM, S.L., WILLIAMS, J.G., 2021, The Analysis of the Frictional Effect on Stress-Strain Data from Uniaxial Compression of Cheese, Journal of Materials Science, 36(9), 2313-2321

Manuscript received: 10.05 .2021 